\title{
Undergraduate education for optical engineering in China under the multidisciplinary education background
}

Jing Qi, Yunjing Ji

Jing Qi, Yunjing Ji, "Undergraduate education for optical engineering in China under the multidisciplinary education background," Proc. SPIE 10452, 14th Conference on Education and Training in Optics and Photonics: ETOP 2017, 104526A (16 August 2017); doi: 10.1117/12.2269931

SPIE Event: 14th Conference on Education and Training in Optics and Photonics, ETOP 2017, 2017, Hangzhou, China 


\title{
Undergraduate education for Optical Engineering in China under the multidisciplinary education background
}

\author{
Qi Jing*a ${ }^{*}$ Ji Yunjing ${ }^{\mathrm{a}}$ \\ ${ }^{a}$ School of Science, Nanjing University of Science and Technology, Nanjing 210094
}

\begin{abstract}
As an basic discipline, Optics is widely used in many fields such as scientific research, industrial applications, art industry, etc.. The industry is facing significant changes at present. Thus talented people acquired multidisciplinary knowledge are needed world widely. To cultivate talents with optical background, both the educators and students need to value the basic disciplinary education. The construction of laboratories for optics disciplinary and the cooperation between different disciplines is also discussed.
\end{abstract}

\section{INTRODUCTION}

Modern disciplines, which are highly differentiated, are trending to integrate with the development of science. The human society is also undergoing a drastic change with the new technological revolution. Population explosion, energy consumption, ecological crisis, etc. posed severe challenges to human. Yet any single discipline was incapable of solving these problems. Therefore people with interdisciplinary background in Humanities, Social sciences and Natural Sciences are needed to address these problems. Colleges and Universities, which basic function is talent training, should pay close attention to the changes of educational concept and content.

Optical Engineering(OE) is the field of study that focuses on applications of optics. It involves many other disciplines in practice use. Educators in OE need to modify traditional training models to meet the social needs. The development of $\mathrm{OE}$ and related undergraduate education in universities is discussed later.

\section{THE DEVELOPMENT OF OE IN CHINA}

The theoretical basis of modern optics is the Maxwell's electromagnetic field theory and Einstein's quantum theory. The modern optical technology had been applied in industry when the Laser was invented. The characteristics of Laser made it possible to use light as the carrier of information and energy. That is the reason why modern optical technologies, including the laser technology, optical information processing technology, and etc., developed rapidly since 1960s. Accordingly, modern optical experiments based on these technologies have become an important part of experimental teaching in Colleges and universities.[1] OE has been developed, on the foundation of the optical information science and technology, into multidisciplinary field by the mutual pervasion cross of material science, precision machinery and manufacturing, computer science, energy science, life science, medicine science and microelectronics technology.

14th Conference on Education and Training in Optics and Photonics: ETOP 2017, edited by Xu Liu,

Xi-Cheng Zhang, Proc. of SPIE Vol. 10452, 104526A · C 2017 ICO, IEEE, OSA, SPIE

CCC code: $0277-786 X / 17 / \$ 18 \cdot$ doi: $10.1117 / 12.2269931$

Proc. of SPIE Vol. 10452 104526A-1 
At present, many colleges and universities in China have OE disciplines. 9 among them, including Zhejiang University, and etc. are of the first class. According to their own development and the advantages, these organizations have formed their own research direction and unique characteristic. Most of these universities have established a Undergraduate major. Huazhong University of Science and Technology is located in Wuhan. It promotes the establishment of Optics Valley, Wuhan. Beijing University of Science and Technology, Changchun University of Science and Technology, Nanjing University of Science and Technology and etc., with their military background, are developing civilian optical technologies. Most colleges and universities have established their own majors based on their own advantages. The distribution and construction information of OE(First class) in China is given by the Table 1 .

Table 1 Distribution and construction information of OE(First class) in China *Administrated by the Ministry of Education **Administrated by the Ministry of industry information ***International Joint Laboratories

\begin{tabular}{|c|c|c|c|}
\hline $\begin{array}{l}\text { TOP OE } \\
\text { Institutions }\end{array}$ & $\begin{array}{l}\text { Main } \\
\text { Directions }\end{array}$ & $\begin{array}{l}\text { Undergraduate } \\
\text { Major }\end{array}$ & $\begin{array}{c}\text { Development of Laboratories } \\
\text { (High level laboratories) }\end{array}$ \\
\hline $\begin{array}{l}\text { Beijing } \\
\text { University } \\
\text { of Science } \\
\text { and } \\
\text { Technology }\end{array}$ & $\begin{array}{l}\text { Optical measurement, } \\
\text { Precision instrument, } \\
\text { Optical information } \\
\text { processing. }\end{array}$ & $\begin{array}{l}\text { Optical } \\
\text { information } \\
\text { science and } \\
\text { technology }\end{array}$ & $\begin{array}{l}\text { Optic-electric teaching experiment center, } \\
\text { Key Laboratory of opto-electronic imaging technology and } \\
\text { system* } \\
\text { Joint Laboratory of information optics, (BUST\& Tokyo } \\
\text { University)*** }\end{array}$ \\
\hline $\begin{array}{l}\text { Changchun } \\
\text { University } \\
\text { of Science } \\
\text { and } \\
\text { Technology }\end{array}$ & $\begin{array}{l}\text { Space optical } \\
\text { communication } \\
\text { technology, } \\
\text { Advanced optical design } \\
\text { and manufacturing, } \\
\text { Optoelectronic } \\
\text { countermeasure and target } \\
\text { recognition technology, } \\
\text { Testing and alignment of } \\
\text { complex optical systems }\end{array}$ & $\begin{array}{l}\text { Optoelectronic } \\
\text { information } \\
\text { science and } \\
\text { Engineering }\end{array}$ & $\begin{array}{l}\text { National Key Laboratory of high power semiconductor laser } \\
\text { technology, } \\
\text { Key Laboratory of optoelectronic measurement and } \\
\text { transmission technology*, } \\
\text { National Defensive Laboratory of laser communication } \\
\text { technology, } \\
\text { Advanced optical manufacturing center (with Hong Kong } \\
\text { Polytech University)***, } \\
\text { Optical design center(with Saint Petersburg State University } \\
\text { of Information Technologies, Mechanics and Optics, } \\
\text { establishing)*** }\end{array}$ \\
\hline
\end{tabular}




\begin{tabular}{|c|c|c|c|}
\hline $\begin{array}{l}\text { Huazhong } \\
\text { University } \\
\text { of Science } \\
\text { and } \\
\text { Technology }\end{array}$ & $\begin{array}{l}\text { Optical fiber technology, } \\
\text { Optics sensing networking } \\
\text { technology, } \\
\text { Laser technology and laser } \\
\text { processing technology. }\end{array}$ & $\begin{array}{l}\text { Optical } \\
\text { information } \\
\text { science and } \\
\text { technology }\end{array}$ & $\begin{array}{l}\text { Wuhan National Laboratory for Optoelectronics } \\
\text { (establishing), } \\
\text { National Engineering Research Center for laser processing, } \\
\text { National Laboratory for next generation Internet access } \\
\text { systems. }\end{array}$ \\
\hline $\begin{array}{l}\text { Zhejiang } \\
\text { University }\end{array}$ & $\begin{array}{l}\text { High precision optical } \\
\text { fiber sensor, Optical } \\
\text { precision imaging and } \\
\text { detection, Micro Nano } \\
\text { photonics, } \\
\text { resolution Super } \\
\text { microscopy imaging }\end{array}$ & $\begin{array}{l}\text { Optoelectronic } \\
\text { information } \\
\text { science and } \\
\text { Engineering }\end{array}$ & $\begin{array}{l}\text { National Key Laboratory of modern optical instruments, } \\
\text { National Engineering Research Center for optical } \\
\text { instruments, } \\
\text { International Joint Laboratory for Photonics*** } \\
\text { (with University of Rochester USA and The Royal Institute } \\
\text { of Technology, Sweden ) }\end{array}$ \\
\hline $\begin{array}{l}\text { National } \\
\text { University } \\
\text { of Defense } \\
\text { Technology }\end{array}$ & $\begin{array}{lr}\text { High energy } & \text { laser } \\
\text { technology, } & \\
\text { Optical fiber } & \text { sensing } \\
\text { technology, } & \text { Nano } \\
\text { photonics, } & \text { Optical } \\
\text { instrument } & \text { and } \\
\text { measurement, } & \\
\text { Adaptive optics. } & \end{array}$ & $\begin{array}{l}\text { Optical } \\
\text { information } \\
\text { science and } \\
\text { technology }\end{array}$ & $\begin{array}{l}\text { Key Laboratory of photonic and phononic crystal } \\
\text { technology* }\end{array}$ \\
\hline $\begin{array}{l}\text { Nanjing } \\
\text { University } \\
\text { of Science } \\
\text { and } \\
\text { Technology }\end{array}$ & $\begin{array}{l}\text { Opto-electronic } \\
\text { information sensing, } \\
\text { Precision optical testing, } \\
\text { Laser physics and } \\
\text { application, } \\
\text { Optical fiber applications. }\end{array}$ & $\begin{array}{l}\text { Optical } \\
\text { information } \\
\text { science and } \\
\text { technology(Engin } \\
\text { eering, Science) }\end{array}$ & Advanced solid Laser Laboratory** \\
\hline $\begin{array}{l}\text { Huazhong } \\
\text { University } \\
\text { of Science } \\
\text { and } \\
\text { Technology }\end{array}$ & $\begin{array}{l}\text { Optical fiber technology, } \\
\text { Optics sensing networking } \\
\text { technology, } \\
\text { Laser technology and laser } \\
\text { processing technology. }\end{array}$ & $\begin{array}{l}\text { Optical } \\
\text { information } \\
\text { science and } \\
\text { technology }\end{array}$ & $\begin{array}{l}\text { Wuhan National Laboratory for Optoelectronics } \\
\text { (establishing), } \\
\text { National Engineering Research Center for laser processing, } \\
\text { National Laboratory for next generation Internet access } \\
\text { systems. }\end{array}$ \\
\hline
\end{tabular}




\begin{tabular}{|c|c|c|c|}
\hline $\begin{array}{l}\text { Nankai } \\
\text { University }\end{array}$ & $\begin{array}{l}\text { Optical information } \\
\text { processing, } \\
\text { Subwavelength-optics and } \\
\text { micro nano scale optical } \\
\text { field, } \\
\text { Femtosecond laser and } \\
\text { material interaction, } \\
\text { Bio-spectral imaging } \\
\text { technology and } \mathrm{THz} \\
\text { devices. }\end{array}$ & \multirow[t]{2}{*}{$\begin{array}{l}\text { Optical } \\
\text { information } \\
\text { science and } \\
\text { engineering } \\
\text { (Nankai U. \& } \\
\text { Tianjin U.) }\end{array}$} & $\begin{array}{l}\text { Key Laboratory of Optoelectronic Information Science, } \\
\text { Photonics Engineering Center. }\end{array}$ \\
\hline $\begin{array}{l}\text { Tianjin } \\
\text { University }\end{array}$ & $\begin{array}{l}\text { Laser and photoelectric } \\
\text { testing technology, } \\
\text { Precision measurement, } \\
\text { Metrology, } \\
\text { Pptoelectronics and } \\
\text { optical communication. }\end{array}$ & & $\begin{array}{l}\text { National Key Laboratory of precision measurement } \\
\text { technology and instruments, } \\
\text { Key Laboratory of optoelectronic information technology* }\end{array}$ \\
\hline $\begin{array}{l}\text { Tsinghua } \\
\text { Univerisity }\end{array}$ & $\begin{array}{l}\text { Optoelectronic } \\
\text { technology, } \\
\text { Photoelectronic } \\
\text { Technology, } \\
\text { Metrology }\end{array}$ & $\begin{array}{l}\text { Measurement and } \\
\text { control } \\
\text { technology and } \\
\text { instrument }\end{array}$ & $\begin{array}{l}\text { National Key Laboratory of precision measurement } \\
\text { technology and instruments, } \\
\text { Key Laboratory of intelligent Microsystems*, } \\
\text { Key Laboratory of high precision navigation technology* }\end{array}$ \\
\hline
\end{tabular}

The research directions in Top OE universities listed in the above table send a clear message that the field of OE is crossed with many other disciplines. Yet multidisciplinary education still faces problems and challenges at present. In China, the scientific research institutions are set up and administered according to disciplines. The barriers among different disciplines block the academic communication. The sharing of Researching and educating resources are also limited.

In 2011, Chinese Ministry of science and Technology issued the "National key Basic Research Development Program Management Approach". Inter-disciplines were supported as key projects in "973 Plan". The development target of national key discipline was clearly pointed out by the State Council in "211 Project". "(University need ) to improve the experimental conditions, enrich the context of disciplines, to cultivate a number of talents whose research field may of related disciplines and be closely linked. The researching resource could be shared, and the training of talents could continue at the academic base. ${ }^{[2]}$ 


\section{UNDERGRADUATE EDUCATION FOR OE}

Computer Science(CS), similar as OE, is crossed with many disciplines when comes to application. The development of OE can benefit from CS' experience.

A good example is Yao Class in Tsinghua University. Yao Class was founded by Prof. Qizhi Yao, world-leading computer scientist in 2005. The class was built with a view to nurture promising undergraduate students in the field of computer science. An international faculty team headed by Prof. Yao has been set up. It has been attached great importance to the cultivation of students' thinking mode and the theoretical and basic knowledge. Graduated students are now making remarkable achievements in the field of computer science and mathematics, physics, life science, economics and other related disciplines. Yao Class has built a model for cultivating innovative talents in accordance with their aptitude and developed an extensive international teaching program. It has been considered as a successful example in China's endeavor to cultivate innovative talents. Yao Class's distinctive model has been acknowledged and supported.[3]

The University of Arizona College of Optical Sciences is one of the premier educational and research institutions in optics and photonics worldwide. Their research program spans from optical engineering to fundamental optical physics, from photonics to image science. The Bachelor of Science in Optical Sciences and Engineering degree is housed in the College of Engineering and administered by the College of Optical Sciences. [4]The undergraduate education aims to provide students with experience in applying optical principles to engineering problems and in developing the laboratory and computer skills needed for a career in optical engineering. Meanwhile, student's skills in effective communication and responsible teamwork are also developed.

The two prestigious institutions both emphasize the education of basic knowledge. Another characteristic is that they also attach great importance on practices. Many problems are from the actual needs of modern society, science and economic development. The practical experience is essential to address these problems.

The laboratory is the main place for students to obtain practical experience in university. To establish a teaching laboratory, firstly, educators need to define the goal. In OE, we aim to teach students the design process and provide them with experience doing open-ended projects. What do we expect? What do we have? What do we need to do? If the students have clear answers to the three questions, a basic conception of the experiment is formed. Skills and experiences, such as adjusting the equipment, analysis of experimental errors,etc., will be accumulated during practices.

The difficulty of utilizing the experiment, in many cases, is the restriction from administration. This is also related to the division of disciplines and specialties in universities and colleges in China.[5] A feasible suggestion is that the experimental resources are integrated and re-arranged by the university. Restrictions could be reduced. Therefore, those who have interests in doing experimental research would have chance to be given access to laboratories.

\section{CONCLUSION}

Nowadays, there are few discipline that are limited to a single subject. In the Classification of Instructional Programs (CIP)2000, Multi/interdisciplinary studies was ranked at the same level with Agricultural sciences, Computer and information science, Engineering, Physical science and etc.. Natural science is classed in Multi/interdisciplinary 
studies. ${ }^{[6]}$ (The CIP was developed by the U.S. Department of Education's National Center for Education Statistics. The purpose of CIP is to provide a taxonomic scheme that will support the accurate tracking, assessment, and reporting of fields of study and program completions activity.) Development in each discipline's own field need transforms in educational ideas, from top to bottom, from the administration department to the university, from the officials to educators.

China's industrialization process is in the transition period. OE should conform to the trend and get prepared for the equipment and talented people. Attach great importance on the teaching of theoretical basis and the acquirement of practical experience. Lastly, the task of education is not only to acquire students with knowledge and skills, but also to foster professional and ethical attitudes and a sense of social responsibility for them.

\section{REFERENCE}

[1] Wang, J.M., Liu, Y.W., He, C.J., Yang, Y.N., Zhang, G.B., Li, X.L. And Ding, B.,"Research on the Teaching System of Modern Optics Experiment," Experiment Science and Technology 12(1),114-116(2014).

[2] Huang, Y. and Feng, Y.,'Discussion on ideas of interdisciplinary construction based on state key laboratory," Experimental Technology and Management 33(2), 220-223(2016).

[3] http://iiis.tsinghua.edu.cn/zh/yaoclass/

[4] http://www.optics.arizona.edu/

[5] Han, X.Y., Zhao, M.S., Gu, Y.Y. and Wu. Z.L.,"Study of the innovative ability cultivation for postgraduates based on the crossing between optical engineering and multi-disciplines," Laboratory Science 18(4), 5-9(2015). [6] https://nces.ed.gov/pubs2002/cip2000/ 